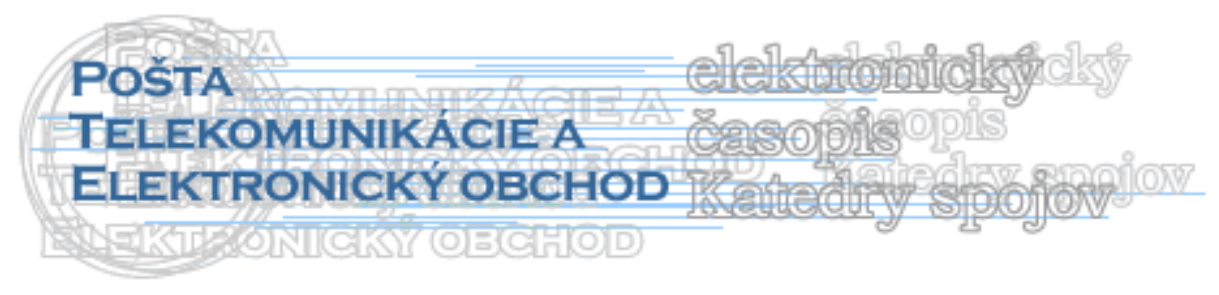

\title{
OHROZUJE SVETOVÁ FINANČNÁ KRÍZA EUROZÓNU?
}

\author{
Anna Pad'ourová ${ }^{1}$ - Mária Mičeková
}

\section{Čo spôsobila finančná kríza?}

Svetová finančná kríza v priebehu 1,5 roka zmazala asi 45 percent hodnoty svetového majetku. Prehlbujúca sa kríza zasiahla finančné trhy prakticky na celom svete a podl'a niektorých odborníkov je najhoršia od čias ,Svetovej hospodárskej krízy“ v medzivojnovom období . Finančná kríza začala v USA, ale od začiatku predstavovala katastrofu aj pre Európu. Podl'a britského denníka Financial Times (FT), kritická situácia v krajinách strednej a východnej Európy (KSVE) je vel'kým rizikom. Možnost' finančného kolapsu práve v týchto krajinách je v súčasnosti najurgentnejším problémom Európskej únie (EÚ). Ak by ho EÚ nedokázala vyriešit', teoreticky by mohol viest' až k rozpadu eurozóny. Podl'a informácií Svetovej banky (SB), má iba štvrtina z najzranitel'nejších krajín dost' prostriedkov na to, aby zabránila nárastu počtu l'udí, ktorí žijú pod hranicou chudoby. Slovensko a Slovinsko, vd’aka prijatiu eura, sú mimo bezprostredného nebezpečenstva.

„Musíme reagovat' $\mathrm{v}$ reálnom čase na rastúcu krízu, ktorá ubližuje l’ud’om $\mathrm{v}$ rozvíjajúcich sa krajinách," uviedol v stanovisku SB jej prezident Robert Zoellick. "Táto globálna kríza potrebuje globálne riešenie a v rámci snáh o jej prekonanie je dôležité, aby sme zabránili katastrofe v rozvojových krajinách. Musíme investovat' do záchranných sietí, infraštruktúry a malých a stredných podnikov, aby sme vytvorili pracovné miesta a vyhli sa sociálnym a politickým nepokojom."[Informovala Svetová banka a agentúra Bloomberg].

Fakt, že sa súčasná kríza vel'mi tvrdo dotkla krajín strednej a východnej Európy (KSVE), spôsobili dve zásadné politické chyby vlád týchto krajín. Prvou chybou, bolo povzbudzovanie domácností v duchu poskytovania hypoték v zahraničných menách. Prejavilo sa to hlavne v Mad'arsku. Skoro každá hypotéka je dnes v tejto krajine, denominovaná v cudzej mene, hlavne v švajčiarskych frankoch. Z hl'adiska postavenia Mad'arska v Eurozóne, by bolo pochopitel'né, keby tieto hypotéky boli v eurách. Aj druhá politická chyba, ktorú urobili predstavitelia vlád KSVE, úzko súvisí s prvou. Vlády nových členských krajín EÚ brali prijatie eura ako dobrovol’né rozhodnutie. To znamená, že nie všade sa prístupové dohody interpretovali rovnako. Noví členovia EÚ nemuseli vstúpit' do eurozóny okamžite. Uvedenými prístupovými dohodami sa zaviazali realizovat' hospodársku a menovú politiku, čo v konečnom dôsledku znamená, že skôr alebo neskôr by k tomuto kroku malo dôjst'.

\footnotetext{
${ }^{1}$ Ing. Anna Pad’ourová, PhD. FPEDAS, ŽU v Žiline, Univerzitná 1, 01026 Žilina, Slovensko, Tel: *421 41 5133129, Fax: *421 415655615

e-mail: anna.padourova@fpedas.uniza.sk

${ }^{2}$ Ing. Mária Mičeková, PhD., FPEDAS, ŽU v Žiline, Univerzitná 1, 01026 Žilina, Slovensko, Tel: *421 41 5133127, Fax: *421 415655615

e-mail: maria.micekova@fpedas.uniza.sk
} 
Dôkazom je Slovensko a Slovinsko, ktoré ukázali, že v prípade správnej politiky bolo možné vstúpit’ do eurozóny dostatočne skoro. Politika odkladania prijatia eura sa zmenila v ostatných krajinách na pohromu, ktorá výrazne narušila ich finančnú stabilitu.

Podl'a britského denníka Financial Times (FT), v konfrontácii s krízou terajších rozmerov sa ukázalo, že nie je výhodné zostat' malou otvorenou ekonomikou na okraji eurozóny s bezvýznamnou menou a vel'kým objemom hypoték denominovaných $\mathrm{v}$ švajčiarskych frankoch.

Pozitívny krok štátov krajín strednej a východnej Európy (KSVE) je aspoň v tom, že zaistili predaj svojich bánk zahraničným vlastníkom. K najaktívnejším kupcom patrili rakúske banky. Angažovanost' rakúskych bánk vo východnej Európe sa rovná asi $80 \%$ hrubého domáceho produktu (HDP) Rakúska. Ďalšie zastúpenie zahraničných bánk v regióne má Taliansko a Švédsko a preto sa kríza systematicky dotýka aj eurozóny.

„Bankové problémy vo východnej Európe sú v súčasnosti zvládnutel'né“, povedal člen Rady guvernérov Európskej centrálnej banky (ECB) Ewald Nowotny. "Som presvedčený, že môžeme zvládnut' všetky problémy východoeurópskych bánk, ale som tiež presvedčený, že podnikatel'ský model minulosti je preč a treba ho zmenit'." Ďalej dodal "Musí to byt' bankový model, ktorý je opatrnejší a obmedzuje úvery v zahraničnej mene. Zároveň to znamená, že už nebudeme mat' rast úverov na úrovni 30 až $40 \%$, ale že budeme mat' stabilnejší bankový systém v dlhom období". Vyzval EÚ, aby zväčšila objem peňazí, ktoré budú k dispozícii pre nových členov únie.

\section{Čaká eurozónu a EÚ vlna bankrotov?}

V tomto roku môže zažit Európska únia vlnu bankrotov. V súčasnosti zmrazené úverové toky paralyzujú firmy. Prognózy predpovedajú prudké kontrakcie európskej ekonomiky a vysokú nezamestnanost'. Očakáva sa, že hrubý domáci produkt (HDP) 16 krajín menovej únie klesne v tomto roku o 2,1 \% a výkon ekonomiky celého 27-členného bloku sa zníži o 2,2 \%. Paralyzovaným firmám môže pomôct' prekonat' dopad globálnej finančnej krízy Európska centrálna banka (ECB) d’alším znižovaním úrokových sadzieb a nákupom cenných papierov firiem, ktoré ,gniavi“ nedostatok úverov. Jednou z d’alších predpovedí je zvýšenie miery nezamestnanosti v eurozóne na 9,5\%. Prognózy tvrdia, že v celej únii bude bez práce približne 4,5 milióna l'udí, z toho len v Španielsku a Vel'kej Británii by mali mat' až 2 milióny nezamestnaných.

V boji s krízou by mali vlády pomáhat' firmám tak, že zrýchlia návrat dane z pridanej hodnoty a d’alšími daňovými refundáciami. Chudobnejší členovia únie sa obávajú, že ich ekonomiky budú $\mathrm{v}$ nevýhode, ak sa budú bohaté štáty pokúšat' vykúpit' si cestu z recesie vel'kými finančnými balíčkami pre svoje ekonomiky. V tieni podpory federálnej vlády USA detroidským automobilkám a v záujme zachovania konkurencieschopnosti sa európske vlády Francúzska a Švédska rozhodli tak isto podporit' národný automobilový trh vo forme niekol'ko miliardových štátnych podpôr. Skupina zamestnávatel'ov preto nalieha na EK, aby pevne presadzovala dodržiavanie pravidiel o štátnej pomoci a konkurencii aj napriek tomu, že niektorí politici žiadajú ich zmiernenie. Jedna z krajín eurozóny - Nemecko, zaviedla takzvanú šrotovaciu prémiu, vo výške 2500,- EUR, každému kto si kúpi nové auto a nechá zošrotovat' najmenej devät' rokov staré. Proti krízové opatrenie pomohlo nielen nemeckým výrobcom áut, ale tiež českej Škodovke, ktorej nová Fabia sa vo februári tohto roku stala druhým najpredávanejším modelom na nemeckom trhu. Na Slovensku sa ukázalo, že šrotovné nie je len o solidarite s ostatnými krajinami čo šrotovné zaviedli, ale o konkrétnej pomoci slovenskej ekonomike. Výber DPH z predaných automobilov by mal prevyšovat' balík, ktorý vláda na šrotovné vyčlenila.

\section{Pomôže EÚ krajinám eurozóny?}

EÚ môže prostredníctvom Medzinárodného menového fondu (MMF) poskytnút' finančnú pomoc. Nie je však isté, či by to vyriešilo krízu týkajúcu sa platobnej bilancie 
regiónu. Ak by pokračoval pokles kurzu mien krajín regiónu, potom sa zvýši počet domácnosti, ktoré nebudú schopné splácat' svoje úvery. V súčasnosti by pomohlo čo najrýchlejšie prijatie eura. Samozrejme, že ho nemôžu tieto krajiny prijat' hned'. Čo však môžu urobit' hned', je predloženie dôveryhodnej a pevnej prístupovej stratégie, kde by mal byt' uvedený dátum vstupu do eurozóny a konverzný kurz.

V printových médiách sa predstavitelia EÚ vyjadrovali, ako informoval nemecký denník Financial Times Deutschland, takto: „Krajiny eurozóny, ktoré by sa stali platobne neschopnými, by za pomoc museli plnit' vel'mi tvrdé podmienky“ povedal predseda Rady ministrov financií a hospodárstva EÚ a luxemburský premiér Jean-Claude Juncker. Vylúčil možnost', že by členom eurozóny pomáhal z platobnej neschopnosti Medzinárodný menový fond (MMF). Odôvodnil to takto: "Ak by sa člen eurozóny musel obrátit' o pomoc na MMF, poškodilo by to povest', solídnost' a solidaritu menovej únie." Ďalej povedal: "Aj keby došlo k platobnej neschopnosti, čo úplne vylučujem, máme $\mathrm{k}$ dispozícii mechanizmy, ktoré sú dostatočné". „Dôležité je, aby krajina, ktorá bude zápasit' s platobnou neschopnost’ou, najprv využila všetky vlastné možnosti na ozdravenie. Až potom, ked’ ich vyčerpá, prichádza do úvahy vhodná pomoc z eurozóny“.

Nemecký spolkový minister Peer Steinbrück aj ekonomický a menový komisár Joaquín Almunia nedávno uviedli, že eurozóna je pripravená na záchrannú akciu platobne neschopným členom svojho spoločenstva.

\section{Literatúra}

[1] https://www.financialtimes.net/

[2] http://hnonline.sk/ekonomika/

[3] http://openiazoch.zoznam.sk/

[4] http://www.e-katalog.sk/spravodajstvo

\section{Grantová podpora}

- VEGA 1/4573/07 „Možnosti, ohraničenia a vývojové tendencie koncepcie univerzálnej služby v pošte a telekomunikáciách v procese globalizácie

- VEGA 1/0468/08 Inovačné stratégie v sektore služieb 